\title{
Characterizations of Collagen Fibers for Biodegradable Films Production
}

\author{
Wolf, K.L. ${ }^{1}$, Sobral, P.J.A. ${ }^{2}$, Telis, V.R.N. ${ }^{1,{ }^{*}}$ \\ ${ }^{1}$ UNESP, Departamento de Engenharia e Tecnologia de Alimentos, São José do Rio Preto, \\ SP, Brazil. "E-mail: vanianic@ibilce.unesp.br \\ ${ }^{2}$ USP, Faculdade de Zootecnia e Engenharia de Alimentos, Pirassununga, SP, Brazil.
}

\begin{abstract}
Elaboration of films containing fibers of crude, insoluble, collagen is intended to be investigated, since collagen partial insolubility and fibrous structure could result in films with improved mechanical properties. The purpose of this work was to determine some chemical and physical-chemical characteristics of collagen fibers obtained from bovine hide. The material showed a high protein content of about $86 \%$, and only moderate solubility at low $\mathrm{pH}$. Protein denaturation was observed when collagen fibers dispersed in water were heated above $50^{\circ} \mathrm{C}$. Denaturation temperature decreased with acidification of the dispersion, indicating lower thermal stability of the protein at low $\mathrm{pH}$.

Keywords: biofilms, biopolymers, protein, composition, solubility, DSC
\end{abstract}

\section{INTRODUCTION}

Collagen is a fibrous protein responsible by structural sustaining of several animal tissues, being the main protein present in skin, bones, tendons, cartilages and teeth. It is also raw material for production of gelatin, cosmetics and foods, as well as an alternative for edible and/or biodegradable films manufacture. Collagen is practically insoluble in water, but lowering the $\mathrm{pH}$ of solution can increase solubility. Insoluble collagen is converted to soluble gelatin by acid or alkaline processing, but whereas products made from native collagen posses significant strength, this strength is lost when soluble collagen is used (Figueiró et al., 2004).

Biopolymers based films are a possible response to demanded environmentally friendly packaging materials, since along with biodegradability they are often derived from abundant and renewable sources, as in the case of collagen produced from bovines, which is available at large scale and feasible cost. Major inconvenient of films obtained from soluble proteins, such as gelatin, is their poor mechanical and water vapor barrier properties, and high water solubility (Fakirov et al., 1997). Elaboration of films containing collagen fibers in its crude form is intended to be investigated, since its partial insolubility and fibrous structure could result in films with improved mechanical properties. Collagen fibers has been used as an ingredient in a variety of meat products due to its water and fat binding abilities, but their physical-chemical properties and its potential use in biodegradable film for food packaging is still little explored. In this context, the purpose of this work was to determine some chemical and physical-chemical characteristics of collagen fibers produced from bovine hide.

\section{MATERIAL AND METHODS}

Chemical composition - Collagen fibers produced from bovine hide (Novaprom Food Ingredients Ltda., Lins, Brazil) were analyzed, in triplicate, to determine protein by the Kjeldhal method ( $\mathrm{N}$ x 5.55); lipids by the method of Bligh and Dyer with cold extraction in chloroform-methanol-water; ash by incineration at $450^{\circ} \mathrm{C}$; and moisture by the gravimetric method in a vacuum oven at $60^{\circ} \mathrm{C}$ for 48 hours (Cecchi, 1999).

Solubility - Suspensions of $2 \mathrm{~g}$ collagen in $30 \mathrm{ml}$ of distilled water had their $\mathrm{pH}$ adjusted with glacial acetic acid or sodium hydroxide, to give different values between 2 and 11. Mass was completed to $100 \mathrm{~g}$ with distilled water, agitated at ambient temperature during $30 \mathrm{~min}$., and centrifuged at $4^{\circ} \mathrm{C}$ by $20 \mathrm{~min}$.. Protein content in supernatant was quantified, in triplicate, by Kjeldhal method $(\mathrm{N} x 5.55)$ and solubility was expressed as the ratio of soluble protein to total protein in suspension (\% w/w) (Monterrey-Quintero and Sobral, 2000). 
Thermal analysis - Aqueous suspensions with $30 \%(\mathrm{w} / \mathrm{w})$ collagen at natural $\mathrm{pH}(7.8)$ and at $\mathrm{pH} 3.0$ (adjusted with glacial acetic acid) were analyzed, in triplicate, in a DSC TA2010 (TA Instruments, New Castle, USA), during heating at $10^{\circ} \mathrm{C} / \mathrm{min}$, between 0 and $100^{\circ} \mathrm{C}$, in inert atmosphere $\left(\mathrm{N}_{2}\right)$. The reference was an empty aluminum pan.

\section{RESULTS AND DISCUSSION}

The collagen produced from bovine hide presented $85.84 \pm 0.55 \%(\mathrm{w} / \mathrm{w})$ proteins, 1.60 $\pm 0.14 \%(\mathrm{w} / \mathrm{w})$ lipids, $2.34 \pm 0.03 \%(\mathrm{w} / \mathrm{w})$ ash, and $9.76 \pm 1.32 \%(\mathrm{w} / \mathrm{w})$ moisture. Olivo and Shimokomaki (2002), analyzing collagen isolated from bovine tendons obtained lower protein $(78.84 \%)$ and higher lipid $(9.28 \%)$ contents, whereas ash $(3.05 \%)$ and moisture $(8.31 \%)$ contents were similar to this work.

In the whole range of $\mathrm{pH}$, solubility varied between $28.9 \%$ and $52.5 \%$ (Figure 1). Maximum solubility was observed at $\mathrm{pH} 2$, whereas minimum solubility occurred from $\mathrm{pH} 6$ to 11 . The region of increasing solubility ( $\mathrm{pH} 5$ to 2) coincides with the range of increasing amount of proton combined with collagen fibers determined by Boki and Kawasaki (1994). When compared to Nile Tilapia myofibrillar proteins evaluated for film formation by Monterrey-Quintero and Sobral (2000), which showed solubility of $96.9 \%$ at $\mathrm{pH} 3$, collagen proteins solubility can be considered low. Nevertheless, this may be a positive characteristic, since soluble collagen products present low strength (Figueiró at al., 2004).

Thermograms of collagen showed wide protein denaturation endotherms during heating. Denaturation temperature was considered as the peak temperature of endotherms (MonterreyQuintero and Sobral, 2000). At natural $\mathrm{pH}$, two peaks were detected, at $51.48 \pm 3.04{ }^{\circ} \mathrm{C}$ and $63.42 \pm 1.41{ }^{\circ} \mathrm{C}$. Two peaks were also observed for collagen at $\mathrm{pH} 3.0$, but peak temperatures were lower: $39.52 \pm 1.84{ }^{\circ} \mathrm{C}$ and $52.54 \pm 2.88{ }^{\circ} \mathrm{C}$, respectively. At $\mathrm{pH} 3.0$, peaks were less defined than at $\mathrm{pH}$ 7.8. The denaturation temperature decreasing indicates lower thermal stability of proteins, as a consequence of conformation change induced by interactions between proteins and hydrogen ions in the acid medium, which lead to higher hydration of collagen. This is in accordance with the high solubility observed at low pH's. Friess and Lee (1996) observed denaturation of insoluble collagen from bovine tendons at $\mathrm{pH} 3.5$ in the range of $35^{\circ} \mathrm{C}$ to $43^{\circ} \mathrm{C}$, and verified experimentally that denaturation was complete and irreversible. Swollen collagen matrices showed a reduction in denaturation temperature, in agreement with results of the present work. Figueiró et al. (2004) measured a denaturation temperature of $52.2^{\circ} \mathrm{C}$ in films made with collagen from bovine serosa at $\mathrm{pH} 3.5$.

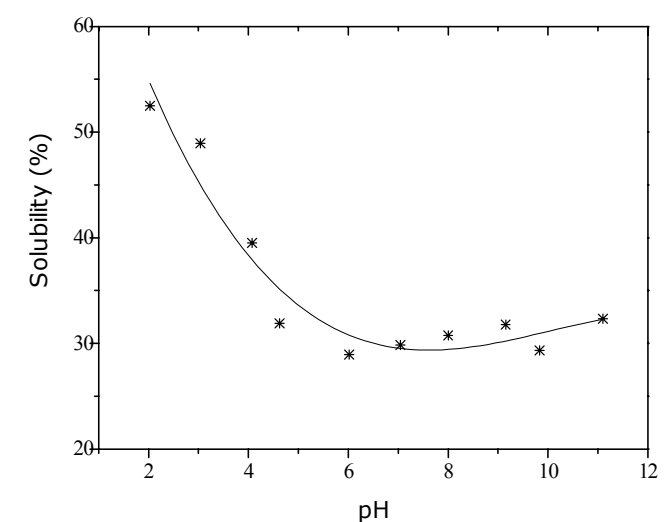

Figure 1. Solubility of collagen (g soluble protein/100 $\mathrm{g}$ total protein in suspension).

ACKNOWLEDGEMENTS - FAPESP and $\mathrm{CNPq}$ for financial support.

\section{REFERENCES}

Boki, K, Kawasaki, N. 1994. Journal of Colloid and Interface Science, 164: 364.

Cecchi, H.M. 1999. Fundamentos Teóricos e

Práticos em Análise de Alimentos, Editora da UNICAMP, Campinas, $212 \mathrm{p}$.

Fakirov, S., Sarac, Z, Anbar, T., Boz, B., Bahar, I., Evstatiev, M., Apostolov, A.A., Mark, J.E., Klocskowski, A. 1997. Colloid and Polymer Science, 274: 334.

Figueiró, S.D., Góes, J.C., Moreira, R.A., Sombra, A.S.B. 2004. Carbohydrate Polymers, 56: 313. Friess, W., Lee, G. 1996. Biomaterials, 17: 2289. Monterrey-Quintero, E.S., Sobral, P.J.A. 2000. Pesquisa Agropecuária Brasileira, 35: 179. Olivo, R., Shimokomaki, M. 2002. No Caminho da Pesquisa - 2a Edição, vol. 1, Editora Imprint, Cocal do Sul, $155 \mathrm{p}$. 